\title{
Corporate social responsibility as a drive to community development and poverty reduction: A stakeholder approach to development in Zimbabwe
}

\begin{tabular}{|c|c|}
\hline \multicolumn{2}{|c|}{$\begin{array}{l}\text { Authors: } \\
\text { Addmore T. Muruviwa }{ }^{1} \\
\text { Fhulu H. Nekhwevha } \\
\text { Wilson Akpan }^{1}\end{array}$} \\
\hline \multicolumn{2}{|c|}{$\begin{array}{l}\text { Affiliation: } \\
\text { 'Department of Sociology, } \\
\text { Faculty of Social Sciences and } \\
\text { Humanities, University of } \\
\text { Fort Hare, South Africa }\end{array}$} \\
\hline \multicolumn{2}{|c|}{$\begin{array}{l}\text { Corresponding author: } \\
\text { Addmore Muruviwa, } \\
\text { amuruviwa@gmail.com }\end{array}$} \\
\hline \multicolumn{2}{|c|}{$\begin{array}{l}\text { Dates: } \\
\text { Received: } 10 \text { Apr. } 2017 \\
\text { Accepted: } 29 \text { Jan. } 2018 \\
\text { Published: } 07 \text { June } 2018\end{array}$} \\
\hline \multicolumn{2}{|c|}{$\begin{array}{l}\text { How to cite this article: } \\
\text { Muruviwa, A.T., } \\
\text { Nekhwevha, F.H. \& } \\
\text { Akpan, W., 2018, } \\
\text { 'The volatility of institutional } \\
\text { arrangements that influence } \\
\text { development: The case of } \\
\text { Bram Fischer International } \\
\text { Airport in South Africa', The } \\
\text { Journal for Transdisciplinary } \\
\text { Research in Southern Africa } \\
\text { 14(1), a440. https://doi. } \\
\text { org/10.4102/td.v14i1.440 }\end{array}$} \\
\hline \multicolumn{2}{|c|}{$\begin{array}{l}\text { Copyright: } \\
\text { @ 2018. The Authors. } \\
\text { Licensee: AOSIS. This wo } \\
\text { is licensed under the } \\
\text { Creative Commons } \\
\text { Attribution License. }\end{array}$} \\
\hline \multicolumn{2}{|l|}{ Read online: } \\
\hline 回的回 & $\begin{array}{l}\text { Scan this QR } \\
\text { code with your } \\
\text { smart phone or } \\
\text { mobile device } \\
\text { to read online. }\end{array}$ \\
\hline
\end{tabular}

Background: The emergence of a 'Southern' discourse of corporate social responsibility (CSR) highlight the crucial issues of poverty reduction, infrastructure development and the broader questions of social provisioning and community development.

Aim: This study builds on existing knowledge to reveal how CSR has become a drive or aid in the community development discourse and poverty reduction mechanisms. This was done through the analysis of major CSR projects by Zimplats mining company.

Setting: The study was carried out in Mhondoro-Ngezi, Zimbabwe, which is in a rural setting. Method: The study employed a triangulated design, with data collected using a mini-survey, focus groups and in-depth interviews.

Results: The key findings are that the fundamental roles of CSR have been to link it to addressing under-development and poverty reduction issues in developing countries.

Conclusion: Through distributional CSR activities, the mining company was able to address the health, educational, employment and water needs of the local people.

\section{Introduction}

Business and society relations have remained a major discussion topic in the academic and research arena over the past decades. This relationship revolves around a number of issues including economic, environmental, ethical and social. Graafland, Eijiffinger and Simid (2004:137) posit that 'the debate in society about the ethical and social aspects of business has forced companies to react to the social and ethical pressure of the public'. According to Carroll and Buchholtz (2009:5), 'although the business system has served society well, criticisms of business and its practices have become commonplace in recent years'. These criticisms have come from the lack of commitment by business to the environmental and socio-economic development of society. Some of the criticisms towards business have come from stakeholders such as the government, civil society organisations, trade unions and local communities in the Global South. In response to the criticisms, business entities in both developed and developing countries have initiated counter-adaptive ways of relating to different stakeholders. Idemudia (2014) supports this assertion by arguing that since the late 1990s corporate social responsibility (CSR) has been used as a tool by private business to initiate fundamental contributions towards improving socio-economic and ecological conditions in Africa.

Scholars such as Levitt (1958) and Friedman (1970) have argued that the primary role of business is to satisfy its shareholders, produce goods and services for the society, and maximise profit. Similarly, Brummer (1983:112) contends that 'business responsibility is to merely meet the objectives of business executives in conformity with the laws and regulations of the government or state'. Critics of this assertion argue that business' obligation should not centre only on profit making and satisfying the needs of its shareholders. Rather, it should incorporate the needs of society at large to address the socio-ecological problems within society (Frooman 1999). Beesley and Evans (1978) argue that the genesis of CSR by business entails or propel social improvements through development in society. The relationship between business and society is now embedded in the concept of CSR. The CSR discourse has been articulated in a variety of ways by different scholars and these ways are related clearly to differing views regarding the role of business in society (Clarke 1998; Lantos 2001). Frooman (1999) posits that the 'stakeholder perspective' is based on the suggestions that besides shareholders, there are other groups or stakeholders that are affected by a company's activities (such as employees or the local community, government, 
etc.) and must be in the company's decision-making plan and also be treated equally with shareholders. In the discussion of contemporary CSR, the stakeholder perspective has become common, such that it is an inescapable phenomenon that defines business and society relations. Freeman (1998) and Clarkson (1995:106) viewed stakeholders as the groups who have a stake in or claim on the firm, and these include suppliers, customers, employees, stockholders, governments and the local community. The utility of the stakeholder perspective in this study is that it allows the identification of the different groups that the mining company is working with/for in its CSR activities in community development projects. The role of business in society has been questioned over the past decades and, therefore, the framing of CSR has sought to bridge this gap with explicit actions and policies that show the role of business in development and its contributions to society. Blowfield and Dolan (2014) raised an important debate of whether business can contribute to development through CSR. Several studies have been carried out to support or dismiss this debate on CSR and development. Idemudia (2014) noted that the notion of CSR and development in Africa is not new and several case studies have been undertaken on this matter in Africa. However, available literature is dominated by accounts from Nigeria, South Africa, Democratic Republic of Congo and Angola. It is against this background that this article seeks to document how CSR has been used as a tool for development and poverty eradication in the Zimbabwean context. Using a stakeholder approach, this study looks at how the Zimplats mining company has implemented CSR initiatives to meet the developmental needs of its stakeholders. With a vast base of natural resources, Zimbabwe has many multinational companies that have invested in natural resources extraction sectors such as mining, forestry and agriculture.

\section{Mining and corporate social responsibility in Zimbabwe}

In Zimbabwe, mining is one of the critical sectors that anchor the economy. According to Hawkins (2009), relative to global standards, Zimbabwe cannot be compared with other African nations as a mineral-rich economy, but it does possess enough quantities of minerals such as platinum, gold, diamonds, methane gas, asbestos, nickel, coal and chromite to generate export earnings in the region of US\$2 billion annually over the medium term and upwards of $\$ 5$ billion a year within 15 years, thereby ensuring that mining remains comfortably the country's largest exporter. According to the Business Herald (2013) the Zimbabwean mining sector has since been officially declared by the government as the centrepiece of Zimbabwe's economic growth in the short to medium term. The sector has been important to the economy as it has grown to become the biggest contributor to gross domestic product, marginally overtaking agriculture with $16.7 \%$ in 2012 and is seen maintaining this position beyond 2018 (Business Herald 2013).

Despite the influx of foreign mining companies in Zimbabwe, issues of social development in the mining communities have remained silent or at a very low level. The government has been the main benefactor of foreign direct investment (FDI) in the country as it has accrued much from the payment of taxes and royalties by foreign mining houses. The mining history in Zimbabwe shows that mining has been instrumental in the development of local communities in rural areas. As a result of the decentralisation policy by the national government, 'Rural District Councils (RDCs) were established to promote rural development in their areas of jurisdiction through the provision of social and infrastructural services' (Mashuku, Chazovachii \& Mamhova 2012:23). These have seen the sprouting of rural growth points, which are the centres of socio-economic growth in the rural areas. Many towns have developed and evolved around mining centres in Zimbabwe, for instance, Shurugwi, Zvishavane, Hwange, Kadoma, Chegutu, Bindura and Bulawayo (Chamber of Mines 2010). Unlike in other African nations such as South Africa, Nigeria, Ghana, DRC and Angola, in Zimbabwe for so long the issues of CSR have been dormant. According to Matahwa (2007), Zimbabwe still lags behind when it comes to CSR as there has not been any legislation encouraging company involvement in social responsibility programmes. The lagging behind of CSR in Zimbabwe can be confirmed by the dearth of literature on the subject matter. Despite having vast natural resources and a liberated market dominated by foreign companies in the mining, agriculture and manufacturing sectors, Zimbabwe has lagged behind on CSR issues with very few studies conducted by local watchdogs.

The only available literature on CSR is mostly in the form of newspaper articles, company reports and case study reports by local research organisations. Companies in the mining, manufacturing, retailing and agricultural sectors have voluntarily carried out CSR in their localities. Major findings by Matahwa (2007) show that most of these CSR initiatives were philanthropic in nature, with very few initiatives going beyond this level. The crafting of such CSR policies was based on what corporations perceived as important for the community and also their implementation plan lacked the participation of the beneficiaries.

\section{Corporate social responsibility and its capacity to address poverty issues}

According to Volkert (2009), corporations have increasingly been seen as development agents that implement CSR strategies that appeal to poverty reduction in the Global South. Although this has been acknowledged, knowledge or evidence of this engagement among the vulnerable groups has remained sparse (Jenkins 2005). This is why Jamali and Mirshak (2007:260) posit that although there has been theoretical research about the impacts of CSR in general, studies on CSR and poverty in developing nations are still particularly lacking. For a long time, poverty issues in the South have always been seen as the domain of mainstream development, where the state comes up with various strategies to minimise or eradicate it. Jenkins (2005:540) argues that although there is potential for CSR to tackle 
poverty, the current CSR agenda is silent on poverty reduction as a major objective. Instead there is overemphasis on environmental issues, labour and human rights. Kapelus (2002) acknowledges that owing to the transnationalisation of opposition to transnational corporations (TNCs), CSR has currently been largely driven by the concerns of northern NGOs, trade unions and consumers who have advocated for better CSR policies. Because of the pressure that is exerted by such groups, TNCs have been concerned chiefly with the potential damage to their reputations and image that may come as a result of media exposure of corporate malpractice. Therefore to improve their ratings on the global scale, CSR policies of most TNCs have tended to focus on the negative, meaning to say that, emphasis has been put on things that corporations should not do (Jenkins 2005). Such inappropriate behaviour includes child labour or violation of human rights and pollution. The focus on these issues has diverted attention from addressing the serious issues of seeking positive development outcomes, such as helping to eradicate poverty. That is why Idemudia (2008:98) calls for a shift in focus, from a 'do no harm' agenda by corporates to a CSR agenda that demonstrates development benefits.

International organisations that have linked CSR to international development goals have a belief that CSR can become a core strategy in the achievement of United Nations Sustainable Development Goals. The debate about the potential of CSR contributing to poverty reduction has seen Blowfield (2007:516) coming up with a hypothesis that questions whether CSR has a direct impact on poverty or not. As a response to this claim, Jenkins (2005:525) states that by following socially responsible practices, business will be more inclusive, equitable and reduce poverty. Nelson (2006:47) gives his support by stating that 'most corporations across all sectors are capable of making a sustainable contribution to poverty alleviation'.

\section{Linking corporate social responsibility and the capability approach}

The best possible way to understand how CSR can be tucked in as a way to avert the poverty crisis, especially in the South, is to integrate Armtya Sen's concept of the Human Development and Capability Approach. Sen (2001) approaches development from a human capability and freedom approach. According to Sen (2001), poverty is a complex, multifaceted concept that requires a different approach of analysis. Whilst other benchmarks on poverty see it as sheer shortage of income, to Sen poverty is defined as a lack of human development that encompasses 'multiple forms of deprivation and social exclusion' (Volkert 2009:393). Sen's work on poverty is based on the hindrance to the capabilities and functioning of people's entitlements. Dreze and Sen (1980) and Williams (1999) define entitlements as the set of alternative bundles of commodities or resources that an individual has at his or her disposal for the realisation of capabilities, and these go beyond income. The implication for the lack of these entitlements and commodities is that there are high chances that capabilities will be greatly constrained and as a result will affect the overall livelihood. Sen (1997) views development as expanding the choices people have to lead lives as a result of exercising their various capabilities and entitlements. Therefore, successful outcomes on poverty can be measured on the basis of a set of commodity bundles such as investment in rural education, employment creation in local communities, empowerment of women and youth and investment in the rural health sector.

\section{Research methods}

This study used a triangulated approach where qualitative and quantitative approaches were utilised. The study acknowledges that the data collection method was predominantly qualitative in nature, with the quantitative aspect coming in to play a complementary role. With an understanding that both qualitative and quantitative approaches have their own weaknesses, the researcher saw it feasible to use both methods to ameliorate any inherent biases or weakness from each of the methods. The field work was carried out in eight different wards in Mhondoro-Ngezi. Using a purposive sampling technique, site visits were made to the village heads, Rural District Council Offices, Zimplats mining company offices and Ministry of Youth, Indigenisation and Economic Empowerment. Eight focus group discussions (FGDs) were employed to engage with the ordinary members of the community, whilst semi-structured interviews were used to capture the data from other individual stakeholders, such as government officials, representatives from the mining company, the Member of Parliament for Mhondoro-Ngezi constituency, local government officials and community leaders. As a follow-up to the qualitative study, a mini-survey was also used in this study. Questionnaires were randomly distributed in the eight wards of the Mhondoro-Ngezi community for the members to answer questions related to the impact of CSR projects by Zimplats on community development. The study also utilised secondary materials where newspaper articles, magazines, government and company reports and research outputs from other organisations were analysed to provide a concrete understanding of CSR matters in Zimbabwe.

\section{Research findings}

The following sections are a presentation of the research findings from the field work conducted in Mhondoro-Ngezi depicting how CSR has been used as a drive to community development in cases where other stakeholders such as the government have failed to make any developmental impacts. The findings are presented in thematic form as they emerged from the field data. The presentation of the findings was done under five themes: (1) distributional CSR initiatives, (2) investment and promotion of rural education in Mhondoro-Ngezi, (3) rural employment creation, (4) health and water facilities in Mhondoro-Ngezi and (5) empowerment of women and youth. 
The general belief among CSR enthusiasts from the South is that business activities must contribute positively to the sustainable development of the local communities in which they operate. Proponents of the resource curse theory argue that despite having an abundance of natural resources some resource-rich nations still remain poor and backward because of ill-informed policies from both the private and public sector. Mhondoro-Ngezi has been pointed out as one of the poorer communities in Zimbabwe, yet it hosts the second largest platinum producer in the world. However, findings from the study present a positive picture of the benefits of CSR initiatives on the development of local community and poverty reduction.

\section{Distributional corporate social responsibility initiatives by Zimplats}

According to Mutti et al. (2012:7), 'the primary objective of distributional CSR is to ensure a visible flow of benefits from the mining projects to surrounding community via investment in schools, healthcare and physical infrastructure'. Idemudia (2011:3) differentiates between macro-level and micro-level CSR indicators. On one hand, micro-level indicators encompass community development efforts where there is prioritization of social investments in social infrastructure provision, such as schools, roads, hospitals and business and community centres. On the other hand, the macro-level indicators involve addressing the factors responsible for community underdevelopment such as environmental degradation; corruption; lack of accountability, transparency and capacity building; and declining manufacturing and agricultural sectors.

Semi-structured interviews with the management of Zimplats indicated that the company has managed to contribute to various development initiatives in the

TABLE 1: Zimplats' expenditure on corporate social responsibility (2000-2013).

\begin{tabular}{lc}
\hline Category & Amount spent in US dollars \\
\hline Road construction and rehabilitation & 31 million \\
Employee housing development & 93 million \\
Support to national power utility & 73 million \\
School development projects & 5 million \\
Medical facilities and equipment & 1.6 million \\
Agriculture and enterprise development & 3.4 million \\
Other philanthropic projects & 2.4 million \\
\hline
\end{tabular}

Source: Derived from the semi-structured interview with Zimplats' corporate services management.
Mhondoro-Ngezi community. From the study empirical evidence from the company's representative noted that the Zimplats has spent millions of dollars on community development projects as part of its CSR activities. Table 1 gives a summary of some of the expenditure by Zimplats towards the development of Mhondoro-Ngezi community.

The above table gives a summary of the money that has been spent by Zimplats in Mhondoro-Ngezi as part of its CSR initiatives. In total, the company has spent US\$209 million on community projects. This is an example of distributional CSR projects designed to benefit the local community in which the mining company is located.

It has been argued that a lot has been said about the actions and inactions of multinational companies (MNCs), but very little is known about the implementation processes of these actions. One of the best ways of analysing the CSR projects in developing countries is to consult the capabilities for poverty reduction as alluded to by Sen in the earlier section. From the emerging themes in the study, the CSR programmes or projects in Mhondoro-Ngezi were classified under areas that include access to education, health, employment, income generating projects, empowerment of women, livelihood enhancement and infrastructure development. Therefore, the following sections are a breakdown of the CSR projects that have been implemented by Zimplats mining company that have aided in the development and social improvement of the Mhondoro-Ngezi community.

\section{Investment and promotion of rural education in Mhondoro-Ngezi}

From the study, it was noted that Zimplats managed to fulfil the following development initiatives as part of its social responsibility to promote rural education, as demonstrated in Table 2.

As noted from the table above, the activities by Zimplats to refurbish the schools around Mhondoro-Ngezi are a sign of the mining company's commitment to improving the educational standards in Mhondoro-Ngezi. The primary and secondary data testifies that Zimplats invested a lot of money $(\$ 5 \mathrm{~m})$ for the construction, refurbishment and renovation of both primary and secondary schools. The school development initiatives focused on different schools in the different wards

TABLE 2: List of schools assisted by Zimplats.

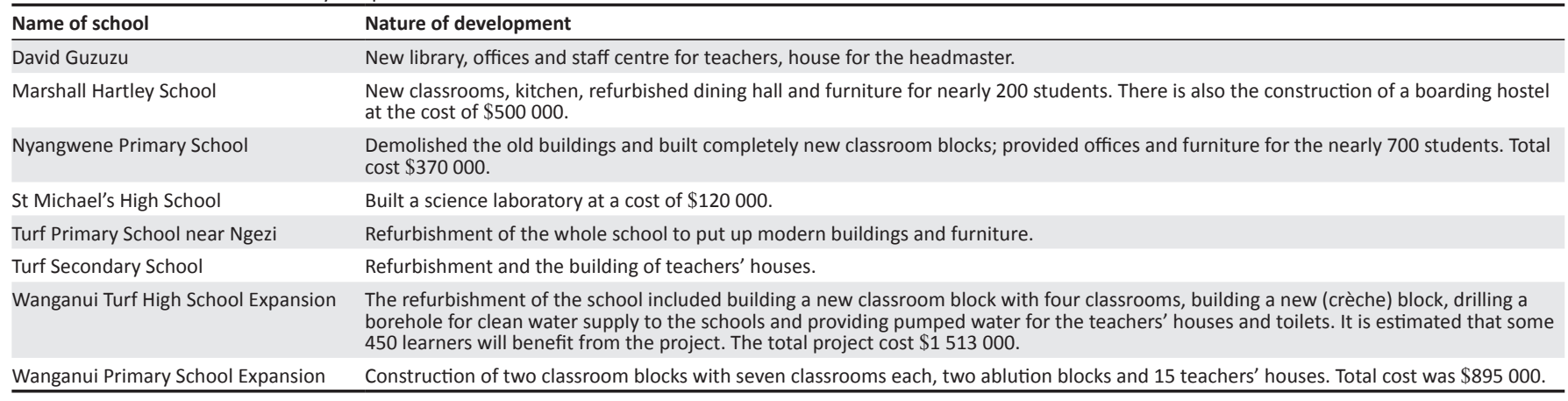

Source: Derived from the semi-structured interview with Zimplats' corporate services management. 
in Mhondoro-Ngezi. Before the intervention of Zimplats, the majority of schools in the area were in a dilapidated state and needed urgent attention.

During the data collection in the community, the residents frequently mentioned development in the educational sector as the most important development initiative at the local level. Extracts from focus group discussions verify some of the initiatives that were carried out by the mining giant in the community as follows:

The company has been involved in the rehabilitation of local schools especially in Turf. The schools were transformed into modern schools like those you find if you go to the bigger cities. (FGD No 2, Interviewee No 3, April 2013)

The idea of investing and promoting education ensures that local children are capacitated with basic knowledge and skills. According to Sen (2003:17), one of the fundamental capabilities to tackle poverty is education because it plays a role in the expansion of capabilities. Sen (2003:27) further points out that 'education makes a child autonomous in terms of creating a new "capability set" for the child'. This is because a well-educated and skilled workforce is able to contribute to social transformation and the enhancement of local livelihoods by accessing employment opportunities. The mining company invested a lot in education so as to ensure that the local young people are able to gain employment opportunities after they complete their studies. Sen's (2003) argument on education is that investing in education creates the expansion of the child's capacity and ability and also widens the opportunities in the future. Therefore, by focusing on human capacity development, the company ensured that its human resource base is equipped with the necessary skills required in the labour market. As shall be shown later, most of the general workforce for the mining company comprises the local people who come from the various wards within the community. Results from the mini-survey concur with the qualitative accounts on the contribution that Zimplats has made in promoting and developing education in Mhondoro-Ngezi community. Figure 1 shows a pie chart with the distribution of responses on the perception of local people about the CSR impact on education.

With $94 \%$ of the respondents acknowledging that Zimplats managed to ensure the development of local schools, one can simply say that business has the potential to support access to education and improve the quality and relevance of education. Proponents of CSR argue that it can play a complementary role where government has failed. In this context, the majority of schools that are supposed to be serviced by the government were neglected for a long period, but with the assistance rendered by Zimplats, most rural schools are able to ensure that their services reach the residents of Mhondoro-Ngezi. Although Mhondoro-Ngezi covers a wide geographical area, the company has made sure that even in the remote areas that are far away from the mine, schools benefit from this programme.

\section{Rural employment creation}

One of the anticipated roles or duties expected of MNCs when they invest in a local community is the creation of employment. Jenkins (2005:536) argues that 'business can help reduce poverty through job creation'. Most MNCs in developing countries have been criticised for their poor labour standards in the host communities. Jenkins (2005:540) posits that a relatively small number of people from developing countries are employed by MNCs and this is likely to constrain the impact of CSR on poverty. Despite all these claims, Zimplats is commended for its contribution towards employment creation for the local people. From the semi-structured interviews with community leaders, it was noted that the mining company directly employs from the local population. Whilst other MNCs bring in their experienced or skilled labour force, Zimplats has relied on the local workforce for its skilled labour and general labour. Most of the miners are selected from the different villages based on their qualifications. In an environment that is characterised by scarce job opportunities, Zimplats is the biggest employer. The government is the second largest employer, with occupations such as nursing, police and teaching being dominant. Table 3 gives a distribution of the employment patterns in Mhondoro-Ngezi community.

Table 3 shows the employment distribution in MhondoroNgezi. From the study it was noted that $37.2 \%$ of the respondents are formally employed both in the private and public sector and $11.6 \%$ of the population is informally

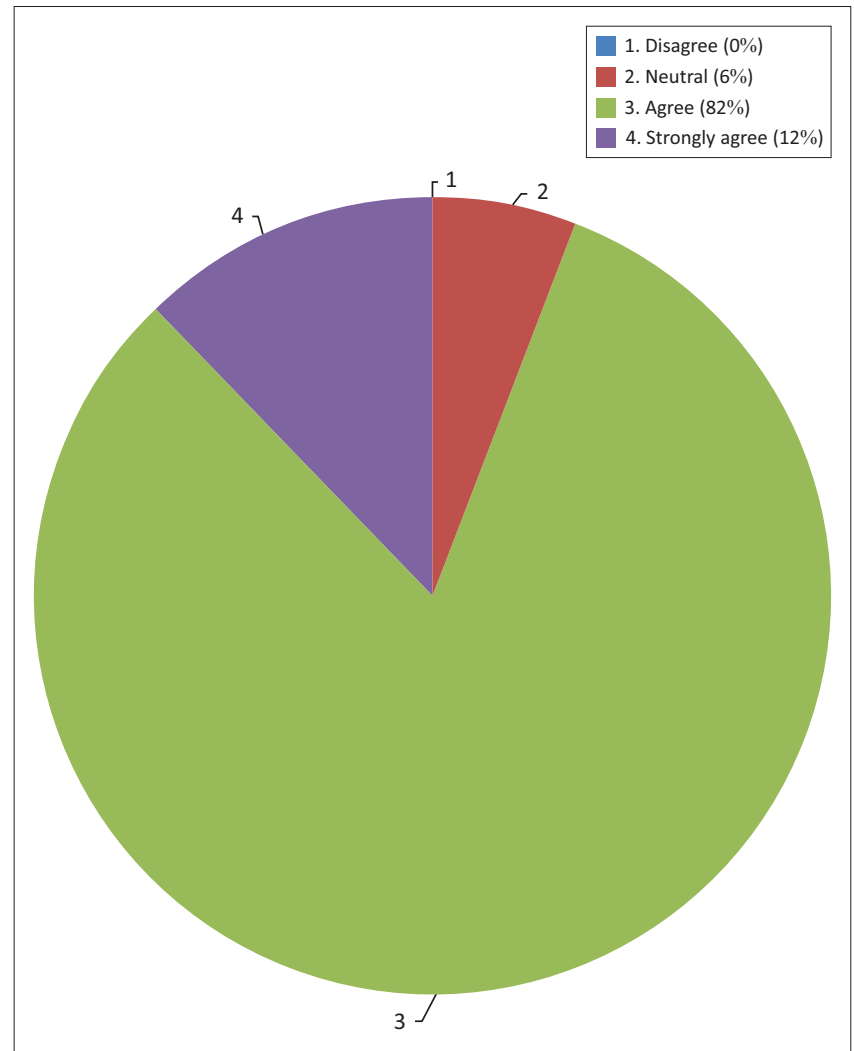

Source: Derived from the survey data and findings in Mhondoro-Ngezi community.

FIGURE 1: Investment in education. Question: Have Zimplats' community projects managed to build both primary and secondary schools in MhondoroNgezi community? 
TABLE 3: Type of employment.

\begin{tabular}{llcccc}
\hline Employment status & Frequency & $\mathbf{\%}$ & Valid \% & Cumulative \% \\
\hline Valid & Formally employed & 80 & 37.2 & 37.2 & 37.2 \\
& Informally employed & 25 & 11.6 & 11.6 & 48.8 \\
& Unemployed & 110 & 51.2 & 51.2 & 100.0 \\
& Total & $\mathbf{2 1 5}$ & $\mathbf{1 0 0 . 0}$ & $\mathbf{1 0 0 . 0}$ & - \\
\hline
\end{tabular}

Source: Derived from the survey data and findings in Mhondoro-Ngezi community.

TABLE 4: Occupations.

\begin{tabular}{llcccc}
\hline \multicolumn{2}{l}{ Occupation } & Frequency & $\mathbf{\%}$ & Valid \% & Cumulative \% \\
\hline Valid & Teacher & 16 & 7.4 & 7.4 & 7.4 \\
& Nurse & 4 & 1.9 & 1.9 & 9.3 \\
& Policeman & 10 & 4.7 & 4.7 & 14.0 \\
& Mine worker & 44 & 20.5 & 20.5 & 34.4 \\
& Other & 141 & 65.6 & 65.6 & 100.0 \\
& Total & $\mathbf{2 1 5}$ & $\mathbf{1 0 0 . 0}$ & $\mathbf{1 0 0 . 0}$ & - \\
\hline
\end{tabular}

Source: Derived from the survey data and findings in Mhondoro-Ngezi community.

TABLE 5: Sustainability of jobs offered by the mining company.

\begin{tabular}{|c|c|c|c|c|c|}
\hline \multicolumn{2}{|c|}{ Measurement } & \multirow{2}{*}{$\begin{array}{c}\text { Frequency } \\
1\end{array}$} & \multirow{2}{*}{$\begin{array}{l}\% \\
0.5\end{array}$} & \multirow{2}{*}{$\begin{array}{c}\text { Valid \% } \\
0.5\end{array}$} & \multirow{2}{*}{$\frac{\text { Cumulative \% }}{0.5}$} \\
\hline Valid & Strongly disagree & & & & \\
\hline & Disagree & 10 & 4.7 & 4.7 & 5.1 \\
\hline & Neutral & 28 & 13.0 & 13.0 & 18.1 \\
\hline & Agree & 140 & 65.1 & 65.1 & 83.3 \\
\hline & Strongly agree & 36 & 16.7 & 16.7 & 100.0 \\
\hline & Total & 215 & 100.0 & 100.0 & - \\
\hline
\end{tabular}

Source: Derived from the survey data and findings in Mhondoro-Ngezi community. Note: These jobs offered by the mining company have been sustainable and have transformed the livelihoods of the local people.

employed, while $51.2 \%$ of the population is unemployed. Because of the mining investment in the local community, the employment figures have since risen to a higher percentage. The reason why the employment figures in Mhondoro-Ngezi seem to be good is that the national unemployment rate currently stands between $80 \%$ and $85 \%$ (Van Wyk 2014), with Zimbabwe being considered as one of the most literate countries in Africa. From the $37.2 \%$ of formally employed people in the community, Zimplats has employed the greater percentage. Table 4 also summarises the distribution of the occupations in Mhondoro-Ngezi, with Zimplats leading the pack.

The table shows that Zimplats employs about $20.5 \%$ of the total population. The government, which is usually considered the biggest employer in the whole country, falls behind Zimplats' employment statistics in Mhondoro-Ngezi. One of the positive issues from the study is that the mining company has ensured that even those people who are not formally employed by the company are subcontracted by various contractors for short-term stints whenever there are local projects to be fulfilled. In one of the interviews with the local leaders, it was revealed that local people were happy with the employment opportunities offered by the mining company, because this has helped them to make a living. With most people relying on agriculture as the main livelihood option, Zimplats' investment in the mining industry has offered young people including women the opportunity to make a living. The positive contribution of Zimplats' employment opportunities on the local people is witnessed by the desire of almost everyone in the community to work for the platinum mining giant. With better working conditions, housing opportunities, medical coverage, pension and all other work-related benefits, Zimplats has made a positive change on the livelihoods of those fortunate members of the community who have had the opportunity to work for the company. The following interview extract captures the view of the local Member of Parliament on employment opportunities in Mhondoro-Ngezi:

We agreed as the board that every general hand (miners) has to come from the communities and it was adopted. I am happy to say that Zimplats employs directly from the community. All the contractors who come to Zimplats have to employ locals. The locals come through the chiefs. The community leadership sits down with their community and present what is needed by the company for one to be employed there. So in total there are about 3000 people from the local community who are employed at the mine directly or indirectly. (Semi-Structured Interview with local MP, April 2013)

The above interview extract is an indication that great strides have been made by both the local community leaders and the company to ensure that local people are able to fight rural poverty through employment. Employment of local people is a positive move towards ensuring that households guard against risks and uncertainties. According to Sen (2001), access to employment opportunities is one of the fundamental capability sets that the poor can use to evade the effects of poverty through income generation. The sustainable livelihoods approach by Scoones (2009) states that for rural people to fight poverty they need to have access to essential assets. Financial and human capitals are some of the idealistic assets that rural households can have to ensure livelihood building blocks. The access to cash enables rural people to adopt different livelihood strategies (Department of International Development 1999). Community members in Mhondoro-Ngezi confirmed that Zimplats offered the best and most sustainable employment package for the locals. Results from the mini survey confirm this assertion.

Table 5 is a testimony of the community's appreciation of the contribution Zimplats has made through the employment of local people. The idea that most of the jobs are full-time and permanent gives local people the certainty that they are able to cope with any uncertainties and also guard against vulnerabilities. To ensure that its employees and other local people are healthy and fit, the mining company has also invested some money into the building and support of the rural health centres and the drilling of public boreholes. The following section discusses some of the CSR projects by Zimplats meant to improve the health and water reticulation processes in Mhondoro-Ngezi community.

\section{Provision of clean water facilities in Mhondoro-Ngezi}

The most notable problem faced by rural dwellers in Africa is the unavailability of clean water and affordable health services. Most people in the rural areas resort to digging water wells on their homesteads for domestic use. For some they rely on water from the nearby natural streams and rivers, the same source of water that is used by their 
livestock. Data from the fieldwork in Mhondoro-Ngezi shows that as part of its community development initiatives, the mining company implemented projects meant to address the water problems in the rural community. This was witnessed by the drilling of more than 25 boreholes at a cost of US\$130,000 for the benefit of the community. The move by the mining company was seen as a way to address the persistent water problems in the community. One of the members from a FGD confirmed the drilling of boreholes by indicating that:

The company also managed to provide tapped water in some areas, mainly the growth point; boreholes have been drilled so that community members can have access to clean water. Most people in Mhondoro-Ngezi have been relying on the traditional wells that they dug on their homesteads. (FGD No 3, Interviewee No 2, April, 2013)

Some of these services are part of the services government should offer to its local residents. However, because of budgetary constraints, the local Rural District Council has over the years failed to address the water problems in the local community. The sealed boreholes were constructed in a way that ensures there is no contamination from external sources. Borehole drilling is one of the community development projects that have had a direct impact on the lives of local people, as this has minimised diseases that come as a result of contaminated water sources. These boreholes can serve up to 30 households per day with water for domestic use. Since most of the rural villages are in a cluster settlement, the boreholes were sunk at the centres of the villages to ensure that all residents have access to them. Key developmental functions such as the provision of basic infrastructure and enabling access to water, electricity, health and education are traditionally associated with the state, but because of the decline in confidence in the state as an agent for development, these roles are now performed by a range of civil society and market actors (Newell \& Frynas 2007). The basic idea is that where the state has failed, business and NGOs can fulfil the duties as a way to reciprocate its investments in local communities.

\section{Investment in health facilities}

As noted from Table 1, which shows Zimplat's expenditures on distribution CSR projects, investment in health has been part of the mining company's development initiatives. The mining company reported spending at least US\$1.6m on refurbishing medical facilities and purchase of equipment for the local clinics. Such an approach has made a positive impact on the lives of the rural community members, who often find it difficult to access health facilities. One of the notable projects that have been done by the company is the purchase of an ambulance for a local community clinic. The ambulance for St Michael's hospital came at a critical time when some patients were carried in scotch carts to the hospital or when pregnant women had to be transported to a nearby hospital in a wheelbarrow owing to the absence of an ambulance to carry patients. The following interview extract reveals how community members have benefited from investment in health in their communities:
The provision of an ambulance to our local clinic will go a long way to assist the residents of Mhondoro-Ngezi community. In emergency cases, we used to struggle to get to a better health institution but now that we have a vehicle this will make it easier. We are grateful for the work done by the mining company. (FGD No 6, Interviewee No 3, April 2013)

This was a reaction to calls by various community leaders who had been concerned by the increasing rates of maternal deaths owing to rural people giving birth at their homes. Some of them would have developed major complications by the time they arrived at the clinic. Persistent calls by community members in Mhondoro-Ngezi were some of the issues that the mining company could not simply ignore or fail to address. Mitchel et al. (1997) argue that the stakeholder approach presents a platform where there is need for managers to assess which stakeholders or groups deserve their attention and urgency. By recognising that local community members were walking long distances to access certain medical services, coupled with the dilapidated state of rural medical centres, the mining company saw it as paramount to respond to the urgent stakeholder call for improved medical facilities.

Unlike urban hospitals with better equipment, rural hospitals have struggled to attend to some health issues because of absence of machinery. As a result of this, some patients are referred to urban hospitals, where they pay more money and transport costs to be attended. To address such challenges, the mining company donated equipment to local hospitals to ensure that local people would not need to travel longer distances to seek medical attention. Such a move was commended by the former vice president of Zimbabwe, Joice Mujuru, when she was commissioning one of the completed projects by the mining company. The following extract from a newspaper article summarises the impact of Zimplats' health initiatives:

I am aware that in the health sector, Zimplats supplied a new ambulance to St Michael's Hospital, assisted Chegutu Hospital with X-ray equipment and rehabilitated Turf Clinic by enhancing its facilities and ensuring the provision of running water and electricity for the benefit of the communities. (Chronicle 06 April 2011)

The corporate services management of Zimplats also confirmed that such projects were fulfilled by the company as part of its CSR initiatives. The success of these projects has been that they have minimised incidences where community members have to travel for long distances to access certain medical services. Members of the community believe that the mining company has made enormous efforts to ensure that they receive the basic health services in their community without having to travel. The following interview extract from the FGDs supports the role played by Zimplats towards development of the community:

Our general view is that, once we have established health systems and schools, this is a great development for the community because everything centres on health and education. We commend our local leaders and the mining company for their 
efforts to develop our community that has been neglected for a very long time. (FGD No 5, Interviewee No 4, April 2013)

The economic and political conditions in Zimbabwe have affected the level and quality of healthcare delivery in most rural areas (Kevany et al. 2012:46). The economic and political factors have seen many government or public health services in the rural areas shutting their doors in the past years (Lee 2009), owing to the acute shortages of drugs, essential medical equipment and limited operational funding. Therefore such factors simply show how Zimplats' CSR initiatives are of importance to the local community. According to McAdam and Leonard (2003), when MNCs engage in CSR initiatives, it reflects their awareness of the impact and potential of their social investments in terms of improving the living standards of indigenous communities.

\section{Discussion}

The analysis of the results of this study have shown that Zimplats mining company has played a fundamental role through CSR projects in Mhondoro-Ngezi for community development purposes and poverty reduction. The point of departure for this article was an acceptance that despite MNCs being considered as engines for social development in developing countries through CSR initiatives, there is little evidence to account for this assertion. Voices and first-hand experiences of the beneficiaries of developmental projects by Zimplats testify that CSR can be used as a developmental tool meant to complement the developmental duties of government towards its people. The paucity of literature on the CSR initiatives by MNCs in Zimbabwe prompted the researchers to have a thorough look at the activities of Zimplats on community development and their capacity to address poverty reduction in an environment where mainstream development through the state has regressed or become dormant. Deductions from the key findings present important contributions that this article can make to the CSR and development nexus. From the study it emerged that Zimplats mining company is guided by a central CSR policy that states the community development programmes to be carried out. Most of the CSR projects that have been applauded by corporate stakeholders (local community members) met and addressed their urgent claims for basic needs such as water, health and education.

Since the stakeholder theory claims that corporations are not only entitled to satisfy the shareholders' needs but also to consider the needs of its stakeholders, it is important to note that through the stakeholder salience approach, corporations also determine the degree of seriousness or urgency of every claim tabled by stakeholders. Not all claims by legitimate stakeholders are treated with urgency by the firm. According to Mitchell, Agle and Wood (1997:867), urgency can be defined as the degree to which stakeholder claims call for immediate attention. The two determinants of urgency of a claim are time sensitivity and criticality (Agle et al. 1999). Criticality of a claim simply refers to the importance of the claim on the relationship to the stakeholder (Mitchell et al.
1997). The importance of the urgent experience for the organisation is that it presents a more imminent impact to organizational activity and therefore elicits an imminent response. Unless a claim is deemed urgent by the corporation, the possibility of it being addressed or attended to is minimal. So many claims for community development have been made by communities in the South but very few have received attention from MNCs. That is the reason why scholars such as Idemudia (2011), Fox (2004), Frynas (2009) and Christian Aid (2004) have been calling for a developmentoriented CSR agenda that transcends the boundaries of business profitability. Indigenous communities in the developing world have demanded better infrastructure, employment opportunities and service delivery in resource extraction communities, but all these claims have fallen on deaf ears as they are the least of urgent priorities for the big corporations. The core objective of this article has been to understand how CSR has been used by Zimplats as a development tool to foster community development and poverty reduction in Mhondoro-Ngezi. Using this aspect of stakeholder salience, the findings clearly show the stakeholders (community members) always had expectations from the mining company that needed urgent attention. In so doing the mining company reciprocated through distributional CSR initiatives to ensure that the developmental concerns of the stakeholders were addressed. In this study, the stakeholder approach was used to analyse how the mining company responded to their stakeholders' demands and claims for CSR activities that addressed their development needs.

\section{Conclusion}

The conclusion derived from this study is that with diverse crises ranging from the social, economic, health related and environmental, CSR in developing countries has been become a complementary mechanism used by businesses to address such issues. In the Zimbabwean context, despite the presence of quite a number of MNCs operating in resourcerich areas, inadequate information has been documented on the role played by these organisations on their role in community development and poverty reduction mechanisms. This study adds to the already-existing work that has been carried out in other African countries such as Nigeria, South Africa, Angola and Ghana on the role played by business in fostering community development through CSR. That is why there are so many expectations from both the government and local communities for business to assist in addressing poverty and development issues through CSR. This article fills in the gap in CSR theorisation on development by documenting how CSR projects in Mhondoro-Ngezi aided community development and mechanisms to reduce poverty.

\section{Acknowledgements Competing interests}

The authors declare that they have no financial or personal relationships which may have inappropriately influenced them in writing this article. 


\section{Authors' contributions}

A.T.M. was the principal investigator in this study who did the write up of the article. A.T.M. played an influential role in data collection. F.H.N. was the co-author who contributed to the organisation and synthesis of the study. W.A. played a key role (as co-supervisor) of the study from which the article is derived, and also helped to shape the core ideas advanced in the article as an expert in Corporate Social Responsibility issues.

\section{References}

Agle, B.R., Mitchell, R.K. \& Sonnenfeld, J.A., 1999, 'Who matters to CEOs? An investigation of stakeholder attributes and salience, corporate performance and CEO values', Academy of Management Journal 42, 507-525. https://doi. org/10.2307/256973

Aguinis, H. \& Glavas, A., 2012, 'What we know and don't know about corporate social responsibility: A review and research agenda', Journal of Management 38(4), 932-968. https://doi.org/10.1177/0149206311436079

Beesley, M. \& Evans, T., 1978, Corporate social responsibility: A reassessment, Croom Helm, London, p. 211. [An early study that attempts to clarify the meaning of corporate social responsibility and how to exercise these responsibilities]

Blowfield, M., 2007, 'Reasons to be cheerful? What we know about CSR's Impact' Third World Quarterly 28(4), 683-695. https://doi.org/10.1080/014365907013 36523

Blowfield, M. \& Dolan, C., 2014, 'Business as a development agent: evidence of possibility and improbability', Third World Quarterly 35(1), 22-42.

Brummer, J.J., 1983, 'In defence of social responsibility', Journal of Business Ethics 2(2), 111-122. https://doi.org/10.1007/BF00381702

Business, H., 2013, 'Minerals earn US1.4 billion dollars', The Herald, 28 October, p. 6.

Carroll, A.B. \& Buchholtz, A.K., 2009, Business and society: Ethics and stakeholder management, Western Cengage Learning, Mason.

Chamber of Mines, 2010, Corporate social responsibility in the mining sector, Whitesands Communications, Harare.

Christian Aid, 2004, Behind the mask: The real face of corporate social responsibility Christian Aid, London.

Clarke, J., 1998, 'Corporate social responsibility: An ethical practice', in J.A. Blake (ed.), Ethical issues in accounting, pp. 184-199, Routledge, London.

Clarkson, M.B., 1995, 'A stakeholder framework for analysing and evaluating corporate social performance', Academy of Management Review 20(1), 65-91.

Department of International Development, 1999, Sustainable livelihoods and poverty elimination, DFID, London.

Dreze, J. \& Sen, A., 2001, Hunger and public action, Clarendon Press, Oxford.

Fox, T., 2004, 'Corporate social responsibility and development: In quest of an agenda', Development 47(3), 26-36.

Freeman, R.E., 1998, 'A stakeholder theory of the modern corporation', in P.L. (ed.), Perspective in business ethics, pp. 171-181, McGraw-Hill, Singapore.

Friedman, M., 1970, 'The social responsibility of business is to increase its profits', The New York Times Magazine, 13 September, pp. 122-126.

Frooman, J., 1999, 'Stakeholder influence strategies', Academy Management 24(2), 191-205.

Frynas, G.J., 2009, Beyond corporate social responsibility: Oil multinational and socia challenges, Cambridge University Press, Cambridge.

Graafland, J.J., Eijifffinger, S.C. \& Simid, H., 2004, 'Benchmarking of corporate social responsibility: Methodological problems and robustness', Journal of Business Ethics 53, 137-155. https://doi.org/10.1023/B:BUSI.0000039404.67854.e1

Hawkins, T., 2009, The mining sector in Zimbabwe and its potential contribution to recovery: Comprehensive economic recovery in Zimbabwe, Working paper series, UNDP, Harare.

Idemudia, U., 2008, 'Conceptualising the CSR and development debate: Bridging existing analytical gaps', Spring 29(1), 91-108. https://doi.org/10.9774/GLEAF. existing analytical gaps
Idemudia, U., 2011, 'Corporate social responsibility and developing countries: Moving the critical research in Africa forward', Progress in Development Studies 11(1), 1-18. https://doi.org/10.1177/146499341001100101

Idemudia, U., 2014, 'Corporate social responsibility and development in Africa: Issues and possibilities', Geography Compass 8(7), 421-435. https://doi.org/10.1111/ gec3.12143

Jamali, D. \& Mirshak, R., 2007, 'Corporate social responsibility (CSR): Theory and practice in a developing country context', Journal of Business Ethics 72(3), 243-262. https://doi.org/10.1007/s10551-006-9168-4

Jenkins, R., 2005, 'Globalisation, corporate social responsibility and poverty', International Affairs 18(3), 525-540. https://doi.org/10.1111/j.1468-2346.2005. 00467.x

Kapelus, P., 2002, 'Mining, corporate social responsibility and the community: The case of Rio Tinto, Richards Bay minerals and the Mbonambi', Journal of Business Ethics 39(3), 275-296. https://doi.org/10.1023/A:1016570929359

Kevany, S., Murima, O., Singh, B., Hlubinka, D., Kulich, M. \& Morin, S.F., 2012, 'Socioeconomic status and health care utilization in rural Zimbabwe: Findings from project accept', Journal of Public Health in Africa 3(13), 46-51. https://doi. project accept', Journal of
org/10.4081/jphia.2012.e13

Lantos, G.P., 2001, 'The boundaries of strategic corporate social responsibility', Journal of Consumer Marketing 18(7), 595-630.

Lee, J., 2009, Health care: Zimbabwe's luxury, viewed 24 May 2013, from http://www. dailykos.com

Levitt, T., 1958, 'The dangers of social responsibility', Harvard Business Review 36(5), 41-50.

Mashuku, A., Chazovachii, C.L. \& Mamhova, T., 2012, 'The delivery of social and infrastructural services by Rural Councils. In search of challenges facing Chivi Rural District Council, Zimbabwe', International Journal of Politics and Good Governance 3(3), 1-31.

Matahwa, O., 2007, 'Zimbabwe CSR still lagging behind', Alliance Magazine, 01 March, pp. 5-6.

McAdam, R. \& Leonard, D., 2003, 'Corporate social responsibility in a total quality management context: Opportunities for sustainable growth corporate governance', The International Journal of Effective Board Performance 3(4), 36-45. https://doi.org/10.1108/14720700310497104

Mitchell, R., Agle, B. \& Wood, D., 1997, 'Toward a theory of stakeholder identification and salience: Defining the principle of who and what really counts', Academy of Management Review 22(4), 853-886.

Mutti, D., Yakovleva, N., Vazquez-Brust, D. \& Di Mareo, H.M., 2012, 'Corporate social responsibility in the mining industry: Perspectives from stakeholder groups in Argentina', Resources Policy 37(2), 212-222. https://doi.org/10.1016/j.resourpol. 2011.05.001

Nelson, J., 2006, 'Leveraging the development impact of business in the fight against global poverty', in L. Brainard (ed.), Transforming the development landscape-the roles of the private sector, pp. 41-54, Brookings, Washington, DC.

Newell, P. \& Fraynas, G.J., 2007, 'Beyond CSR? Business poverty and social justice: An introduction', Third World Quarterly 28(4), 669-681. https://doi.org/10.1080/ 01436590701336507

Sen, A., 2001, Poverty and famines: An essay on entitlements and deprivation, Clarendon Press, Oxford

Sen, A., 2003, 'Amartya Sen's capability approach to education: A critical exploration', Journal of Philosophy of Education 37(1), 17-33. https://doi.org/10.1111/14679752.3701002

Sen, A.K., 1997, 'From income inequality to economic inequality', Southern Economic Journal 64(2), 384-401. https://doi.org/10.2307/1060857

Scoones, R., 2009, 'Livelihoods perspectives and rural development', Journal of Peasant Studies 36(4), 1-13. https://doi.org/10.1080/03066150902820503

The Chronicle, 2011, 'Zimplats builds houses', The Chronicle, 06 April, pp. 6-7.

Van Wyk, A., 2014, Is Zimbabwe's unemployment rate $4 \%, 60 \%$ or $95 \%$ ? Why the data is unreliable?, viewed 09 October 2014, from https://africacheck.org/reports/iszimbabwes-unemployment-rate-4-60-or-95-why-the-data-is-unreliable/

Volkert, J., 2009, 'Companies as agents of overcoming poverty and development. Their contribution out the view of Ordoliberalism and capability approach', in I. Ordo (ed.), Yearbook for the arrangement of economy and public Stuttgart, pp. 389-413, Lucius and Lucius.

Williams, G., 1999, Assessing poverty and poverty alleviation: Evidence from West Bengal, Blackwell Publishing, Somerset. 